\title{
EFFECT OF DIFFERENT TYPES OF FOOD ON DEVELOPMENT AND FECUNDITY OF PREDACIOUS MITE NEOSEIULUS BELLINUS WOMERSLEY (ACARI: PHYTOSEIIDAE)
}

\author{
WALAA R. ABOU ZAID AND GHADA S. REFAEI
}

Plant Protection Research Institute, ARC, Dokki, Giza

(Manuscript received 10 May 2011)

\begin{abstract}
Phytoseiids mites are known as cosmopolitan predators throughout the world. They have a wide range of natural foods, though preferences may be shown for certain foods on which development may be faster and egg production greater than on others. Data herein showed that Neosiulus bellinus was able to complete development and reproduce when fed on eggs of Tetranychus urticae Koch and AD-1 with a survival rate reached 90 and $60 \%$ respectively. However, it could not survive when fed on AD-2 and AD-3 artificial diets. On the other hand, Adult female longevity of phytoseiid mite $N$. bellinus was found to be longer when fed on eggs of spider mites than the experimental diet AD-1 as was the oviposotion period. Female fecundity was also greatest on eggs of spider mite. While, adult was short lived when no food source offered. Moreover, the survival rates of adult females fed AD-1 after long term maintenance10, 20, and 30 days was 35, 21 and $6 \%$, respectively.
\end{abstract}

\section{INTRODUCTION}

Mites from family Eriophyidae, Tenuipalpidae and Tetranychidae severally attack several annual and perennial crops. Because spider mites have been developing resistance to a series of acarisides (Crof and vande Baan 1988), mites of the family Phytoseiidae have received considerable attention for the last four decades because of their potential as biological control agents of phytophagous mites. According to the life styles phytoseiid could be classified as follows: Type I, specialized predators of Tetranychus species represented by the Phytoseiulus species Type II, selective predators of tetranychid mites (most frequently associated with species that produce dense webbing) represented by Galendromus, some Neoseiulus, and a few Typhlodromus species, Type III, generalist predators represented by some Neoseiulus species and most Typhlodromus and Amblyseius species as well species in all other genera about which information is available, Type IV, specialized pollen feeders/generalist predators represented by Euseius species (McMurtry and Crof, 1997). 
To serve as a viable alternative food source, an artificial diet must be able to maintain phytoseiid mites over the long term rather than increase the capacity for egg production, because an over abundance of phytoseiid mites can lead to an overconsumption of the food resources and may cause an increase in the frequency of cannibalism (Schausberger 2003 and Ogawa and Osakabe 2008).

Therefore, in this study, we discussed developmental success and survival of Neoseiulus bellinus on different food source including three different types of artificial diets.

\section{MATERIALS AND METHODS}

\section{Effect of different food source on life cycle of phytoseiid mite, Neosiulus bellinus}

This experiment was carried out under laboratory conditions $\left(25 \pm 3{ }^{\circ} \mathrm{C}, 65-75\right.$ $\%$ ). A pure culture of predator $N$. bellinus was maintained on the two-spotted spider mite, Tetranychus urticae as the main food source on grapefruit leaves on cotton wool soaked in water in Petri dishes, $9 \mathrm{~cm}$ in diameter.

\section{Preparation of artificial diets:}

During experiment, we prepare artificial diet with different concentration and composition of honey, sucrose, tryptone, yeast extract, fresh egg yolk and distilled water as shown in table (1) According to (Kennett and Hamai 1980 and Ogawa and Osakabe 2008)

During preparation honey, sucrose and tryptone were dissolved in appropriate amounts of distilled water and then filter. The yeast extract and egg yolk were mixed into the filtrate and distilled water was added to adjust the weight appropriately.

Table 1. Concentration and components of different types of artificial diets used

\begin{tabular}{|l|c|c|c|}
\hline Components & $\begin{array}{c}\text { Artificial diet 1 } \\
\text { (AD-1) }\end{array}$ & $\begin{array}{c}\text { Artificial diet 2 } \\
\text { (AD-2) }\end{array}$ & $\begin{array}{c}\text { Artificial diet 3 } \\
(\text { AD-3) }\end{array}$ \\
\hline Honey dew & 5 & 5 & --- \\
\hline Sucrose & 5 & 5 & --- \\
\hline Tryptone & 10 & --- & 5 \\
\hline Yeast & 10 & --- & 5 \\
\hline Egg yolk & 10 & 10 & 10 \\
\hline
\end{tabular}




\section{Rearing cells:}

To notice the developmental stages and egg production of phytoseiid mites, we used modified Munger cells to individually rear $N$. bellinus. Each cell consists of a transparent acrylic board (top board $40 \times 40 \mathrm{~mm}$ ) with a hole in the center this hole covered with clear food-wrap film and was pierced with fine needle for mite respiration. A black acrylic board (middle board) with a hole in the center and a black acrylic board (bottom board) with 1-mm diameter hole in the center pluged with a piece of cotton rope saturated with distilled water and a piece of filter paper that had absorbed $2 \mu \mathrm{l}$ of liquid artificial diet placed on bottom board

\section{Development of Neoseiulus bellinus on different food sources including artificial diets:}

Development of Neoseiulus bellinus was detected on different artificial diets, AD-1, AD-2 and AD-3 and eggs of T. urticae.

Eggs of $N$. bellinus were transferred from mite cultures to cells individually, where $A D(1), A D(2)$ and $A D(3)$ were supplied to each cell. 20 eggs were used for the experiment testing. The observation was carried out through the clear food wraps using a stereo-binocular microscope every day until adult emergence. Slide specimens of all developed adults were prepared using Hoyer medium (Gutierrez 1985).

Comparison between using Tetranychus urticae or artificial diet as a food source of phytoseiid mite Neosiulus bellinus on egg production, longevity, fecundity.

Adult of $N$. bellinus females were isolated and held for mating with males for $24 \mathrm{~h}$. A total of 30-mated females were individually isolated on 30 replicates sets with the two spotted spider mite eggs and AD-1. While control ones received water only. Laboratory observations were made every $24 \mathrm{~h}$ for recording number of eggs laid per female mite.

\section{Long term changes in survival rate and egg production of phytoseiid mite, Neosiulus bellinus adult females when fed on AD1}

Large numbers of $N$. bellinus eggs were isolated from culture to grapefruit leaves on cotton wool soaked in water in Petri dishes, $9 \mathrm{~cm}$ in diameter. Where, hatched individuals were reared on T. urticae. After 5 days, 20, 40 and 80 adult females were then placed into rearing cells where AD-1 was supplied and maintained for 10,20 and 30 days, respectively. The rearing cells were changed by new one every two weeks. 


\section{RESULTS AND DISCUSSION}

\section{Effect of different food source on life cycle of phytoseiid mite, Neosiulus}

\section{bellinus}

Data in table (2) showed that Neosiulus bellinus was able to complete development and reproduce when fed on egg of $T$. urticae and AD-1 with a survival rate reached 90 and $60 \%$, respectively. However, feeding phytoseiid mite, N. bellinus on AD-2 and AD3 artificial diets resulted in equal numbers of deposited eggs while, immature and adult stages could not survive. Similarly, several authors studied the effect of artificial diets (and their different components) in the development of phytoseiid mites (Kennett and Hamai 1980, Shih et al., 1993 and Ogawa and Osakabe 2008) they found that Pollen and powdered mildew are high quality foods and may serve as alternative food sources on which phytoseiid mites can develop and reproduce (Osakabe 1988, McMurtry and Croft 1997, Zemek and Prenerova 1997 and Nomikou et al., 2003)

However, In the present study it was recorded that the phytoseiid mite, $N$. bellinus developed well on AD-1 while it could not survived on AD-2 or AD3 this may explain the fact that, these predators could not complete their development in the absence of saccharides (AD-3) or yeast (AD-2) from diet components (Ogawa and Osakabe 2008).

Table 2. Survival rate of Neosiulus bellinus when feed on different diets

\begin{tabular}{|c|c|c|c|}
\hline & $\begin{array}{c}\text { NO. OF } \\
\text { EGGS }\end{array}$ & $\begin{array}{c}\text { NO. OF DEVELOPED } \\
\text { INDIVIDUALS }\end{array}$ & SURVIVAL \% \\
\hline AD-1 & 20 & 12 & $60 \%$ \\
\hline AD-2 & 20 & 0 & $0 \%$ \\
\hline AD-3 & 20 & 0 & $0 \%$ \\
\hline EGG OF T. & 32 & 28 & 90 \\
\hline URTICAE & & & \\
\hline
\end{tabular}


Comparison between using Tetranychus urticae or artificial diet AD-1 as a food source of phytoseiid mite Neosiulus bellinus on egg production, longevity, fecundity.

Results in table (3) revealed that adult female longevity of phytoseiid mite Neosiulus bellinus was found to be longer when fed on eggs of spider mites, $T$. urticae than the experimental diet AD-1 as was the oviposotion period. Female fecundity was also greatest on eggs of spider mite, followed by AD-1 with the average number of eggs laid /female $32.5 \pm 7.2$ and $12.1 \pm 2.6$, respectively. On the other hand, adult of $N$. bellinus was short lived when no food source offered. Also, (Toyoshima and Hinomoto 2004 and Gotoh et al., 2006) found that N. californicus survived longer when fed on Tetranychus kanzawai.

Table 3. longevity, fecundity and consumption rate of adult female of $N$. bellinus when fed on different diet

\begin{tabular}{|c|c|c|c|}
\hline DIETS & $\begin{array}{c}\text { EGG OF } T . \\
\text { URTICAE }\end{array}$ & AD-1 & STARVING \\
\hline LONGEVITY & $43.4 \pm 3.8$ & $16.7 \pm 5.2$ & $1.1 \pm 0.7$ \\
\hline OVIPOSTION & $23.7 \pm 5.4$ & $9.9 \pm 1.0$ & 0 \\
\hline FEMALE EGGS & $32.5 \pm 7.2$ & $12.1 \pm 2.6$ & 0 \\
\hline EGGS/ DAY & $1.59 \pm 2.8$ & $0.98 \pm 4.6$ & 0 \\
\hline
\end{tabular}

Long term changes in survival rate and egg production of phytoseiid mite, Neosiulus bellinus adult females when fed on AD1

In the present study, results indicated that the survival rates of females provided AD-1 was found to be 35, 21 and $6 \%$ after the 10, 20, and 30 days, respectively. These results strongly suggest that in terms of long-term survival, an artificial diet may be useful as an alternative food source for Neosiulus (Ogawa and Osakabe 2008).

Generally, it could be conclude that phytoseiids mites considered the most effective family used in agricultural system for the biological control of spider mites. However, the availability of food source is fluctuated according to surrounding environmental effects Thus, it is difficult to maintain supplies of this food source. So, using artificial diet to manipulate their population is widely accepted. The present study cleared that artificial diets play an important roles as alternative food sources of phytoseiid mite, N. bellinus. 


\section{REFERENCES}

1. Crof B. A., H. E. vande Baan. 1988. Ecological and genetic factors influencing evaluation of pesticide resistance in tetranychid and phytoseiid mites. Exp. Appl. Acarol. 4:277-300.

2. Gotoh. T., A. Tsuchiya, Y. Kitashima. 2006. Influence of prey on development performance, reproduction, and prey consumption of Neoseiulus califorinucs (Acari: Phytoseiidae). Exp. Appl. 40:189-204.

3. Gutierrez J. 1985. Mounting techniques. In: Helle W, Sabelis MW (eds) Spider mites, their biology, natural enemies and control, vol 1A. Elsevier, Amsterdam, pp 315-353

4. Kennett C. E., J. Hamai. 1980. Oviposition and development in predaceous mites fed with artificial and natural diets (Acari: Phytoseiidae). Entomol. Exp. Appl .28:116-122. doi: 10.1007/BF00287120

5. McMurtury J. A., B. A. Croft. 1997. Life- styles of phytoseiid mites and their roles in biological control. Annu. Rev. Entomol. 42:291-321. doi:10.1146/annurev.ento.42.1.291

6. Nomikou M., A. Janssen, M.W. Sablies. 2003. Phytoseiid predators of whiteflies feed and reproduces on non-prey food sources. Exp. Appl. Acarol. 31:1526.doi:10.1023/B:APPA.0000005142.31959.e8

7. Ogawa Y., Osakabe. 2008. Development, long-term survival, and the maintenance of fertility in Neoseiulus californicus (Acari: Phytoseiidae) reared on an artificial diet. Exp. Appl. Acarol, 45:123-136

8. Osakabe M. H. 1988. Relationships between food substances and developmental success in Amblyseius sojaensis Ehara (Acarina: Phytoseiidae). App. Entomol. Zool. 23: 45-51.

9. Schausberger P. 2003. Cannibalism amoung phytoseiid mites: a review. Exp. Appl. Acarol. 29:173-191.

10. Shih C.I., H. Y. Chang., P. H. Hsu, Y.F. Hwang. 1993. Responses of Amblyseius ovalis (Evans) (Acarina: Phytoseiidae) to natural food resources and two artificial diets .Exp. Appl. Acarol. 17:503-519

11. Toyoshima S., N. Hinomoto. 2004. Intraspecific variation of reproductive characteristic of Amblyseius californicus (Mc Gregor) (Acarina: Phytoseiidae). Appl. Entomol. Zool. 39:351-355.

12. Zemek R., E. Prenerova. 1997. Powdery mildew (Ascomycotina:Erysiphales) an alternative food for the predatory mite Typhlodromus pyri Scheuten (Acari: Phytoseiidae).Exp. Appl. Acarol. 21:405-414. 
دراسة تأثير أنواع مختلفة من الغذاء على تطور و خصوبة المفترس Neosiulus bellinus Womersley

$$
\begin{aligned}
& \text { ولاء ابو زيد ، غادة رفاعى } \\
& \text { معرج بحوث وقابة النباتات - مركز البحوث الزراعية - الدقى - الجبزة. }
\end{aligned}
$$

أجرى هذا البحث لدر اسة تأثير بعض انو اع الاغذية المختلفة على تطور و خصوبة

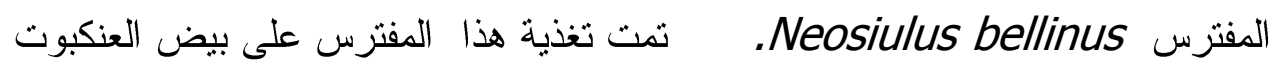

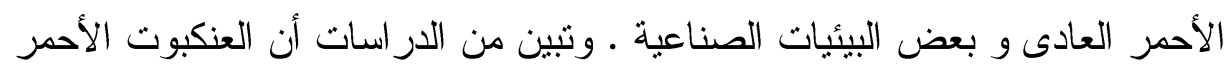

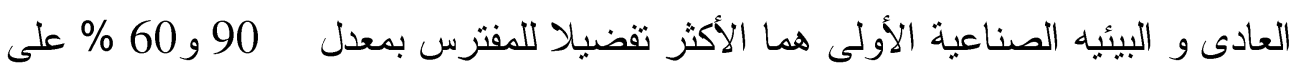

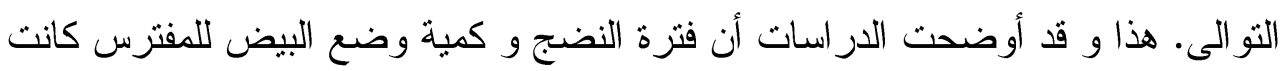

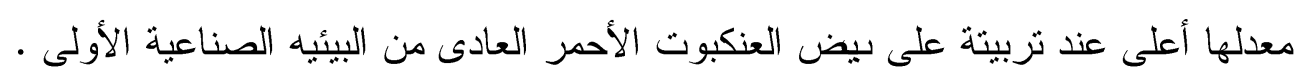
هذا و وقد سجل معدل حياة المفترس عند تربيئة لفترات طويلة (10,20,30) على البيئيه الصناعية الأولى نسبة 35 ،21 و 6 \% على معلى التوالى. 